\title{
KONTEKSTUALISASI DOKTRIN ASWAJA SEBAGAI UPAYA PENINGKATAN EKONOMI UMAT
}

\author{
Muhksinun \\ Institut Agama Islam Nahdlatul Ulama Kebumen \\ mukhsinun.kebumen@gmail.com
}

\begin{abstract}
Nahdlatul Ulama (NU), one of Indonesia's most influential Muslim organizations, should strive to promote its proselytizing in all dimensions. It is intended to reach everyone in the multi-ethnic stratum of Indonesian society. This is one of the important agendas to address the nation's various problems. This paper attempts to define the term "Aswaja" as the spread of Islamic teachings in a wise and simple, but encompassing all aspects of the problem of nationality. This paper concludes that NU needs to try to build programs and movements on economic issues, political issues, education issues, health issues in a better way. So, NU as one of the leading Islamic organizations is required to be more active in nationality issues with Aswaja principles. Although nu has been recognized as a puritanical movement that seeks to separate Islam from other elements that are contrary to the Quran and as-Sunnah (sayings and deeds of the Prophet Muhammad outside the Qur'an), but NU still has to pay attention to economic, educational, and health issues because of all inseparable from religious affairs (Islam). Thus, NU's contribution to the nation and state will be truly felt.
\end{abstract}

Keywords: NU, Contextualization, Aswaja, National Issues, People's Economy.

\begin{abstract}
ABSTRAK
Nahdlatul Ulama (NU), salah satu organisasi Muslim paling berpengaruh di Indonesia harus berusaha untuk menggalakkan dakwahnya dalam semua dimensi. Hal itu dimaksudkan untuk menjangkau semua orang di lapisan multi-etnis masyarakat Indonesia. Hal ini adalah salah satu agenda penting untuk mengatasi berbagai macam masalah bangsa. Tulisan ini mencoba untuk mendefinisikanistilah "Aswaja" sebagai penyebaran ajaran Islam dalam yang bijaksana dan sederhana, tetapi mencakup semua aspek dari problematika kebangsaan. Tulisan ini menyimpulkan bahwa NU perlu untuk berusaha membangun program dan gerakan dalam isu ekonomi, isu politik, isu pendidikan, isu kesehatan dengan cara yang lebih baik. Jadi, NU sebagai salah satu organisasi Islam terkemuka dituntut untuk lebih aktif dalam masalah kebangsaan dengan prinsip Aswaja. Meskipun selama ini NU telah diakui sebagai gerakan puritan yang berusaha untuk memisahkan Islam dari unsur-unsur lain yang bertentangan dengan al- Quran dan as-Sunnah (ucapan dan perbuatan Nabi Muhammad luar Qur'an), tetapi NU masih harus
\end{abstract}


memperhatikan isu-isu ekonomi, pendidikan, dan kesehatan karena semua tidak dapat dipisahkan dari urusan agama (Islam). Dengan demikian, kontribusi NU terhadap bangsa dan negara akan benar-benar dirasakan.

Kata Kunci: NU, kontekstualisasi, aswaja, persoalan bangsa, Ekonomi umat.

\section{PENDAHULUAN}

Andai Mary Evelyn Tucker, seorang Guru Besar Teologi dari Bucknel University yang juga dikenal sebagai sosok pemerhati masalah sosial keagamaan, melihat krisis multidimensional yang terjadi di dunia saat ini-termasuk di Indonesia-mungkin ia tidak akan terkejut sama sekali. Mary Evelyn Tucker pernah mengatakan, krisis multidimensional yang menyerang kita dari banyak arah, baik dalam dimensi ekonomi, politik, pendidikan, budaya, tidak mungkin dapat dipecahkan kecuali didorong oleh kiprah dan peran serta agama berikut organisasi-organisasi keagamaan. ${ }^{1}$

Statemen Mary Evelyn Tucker, di satu sisi, mengindikasikan bahwa penanggulangan berbagai macam krisis dan ragam ketimpangan sosial seperti kemiskinan, krisis ekonomi (lemahnya nilai tukar rupiah dari dolar), problematika penegakan hukum, akses pendidikan yang tidak merata, pelayanan kesehatan yangtidak terjangkau oleh orang miskin, tidak cukup hanya dilimpahkan kepada pemerintah tanpa melibatkan unsur organisasi keagamaan seperti Nahdlatul Ulama (NU). Pada sisi yang lain, statemen ini juga bermakna bahwa berbagai elemen masyarakat khususnya organisasi keagamaan cenderung bersikap "acuh" terhadap berbagai macam persoalan kekinian-dengan tidak mengatakan hanya "sibuk" dalam isu-isu yang tidak populissehingga ragam persoalan kemasyarakat sulit dicegah. Oleh karena itu, tulisan ini bermaksud membahas persoalan-persoalan kekinian seperti persoalan ekonomi (kemiskinan), problematika penegakan hukum, akses pendidikan yang tidak merata, pelayanan kesehatan yang tidak terjangkau oleh orang miskin, serta berupaya mencari solusi melalui peran serta NU yang dianggap paling masuk akal. Dalam rangka itu, sebagai sebuah kajian, tulisan ini berupaya mengkontekstualisasikan doktrin ahlu alsunnah wa al-jamaah (aswaja) sebagai paham keagamaan NU yang penulis anggap

${ }^{1}$ Statemen Mary Evelyn Tucker ini pernah diabadikan Eric Katz dalam bukunya, Judaism and the Ecological Crisis (1994). Buku ini sebenarnya berbicara tentang persoalan ekologi dan kontribusi agama dalam mencegah kerusakan lingkungan. Namun, dalam uraiannya, Eric Katz juga menyinggung statemen Mary Evelyn Tucker dalam konteks krisis multidimensional. Menurutnya, berbagai macam krisis bisa dicegah dengan lahirnya kiprah dan peran serta agama serta organisasi keagamaan seperti NU, Muhammadiyah, dan lain-lain. Lihat, Eric Katz, Judaism and the Ecological Crisis dalam Mary Evelyn Tucker \& John A. Grimm (Ed), Worldviews and Ecology: Religion, Philosophy, and the Environment, (New York: Orbis Books, 1994), hlm. 56. 
sebagai salah satu solusi untuk mengatasi krisis multidimensional yang terjadi di Indonesia saat ini.

\section{PROBLEMATIKA SOSIAL EKONOMI DAN PERAN NU}

Salah satu problematika sosial yang terjadi di Indonesia saat ini adalah ancaman krisis ekonomi dengan ditandai oleh melemahnya nilai tukar rupiah terhadap dolar. Hingga tulisan ini dibuat, dalam kurs tengah Bank Indonesia (BI) mencatat nilai tukar rupiah bergerak melemah menjadi $\mathrm{Rp} 14.178$ dibandingkan sebelumnya di posisi Rp 14.160 per dolar AS. Situasi ini tentu saja mengakibatkan ketidakstabilan perekonomian bangsa Indonesia. Dampak yang paling terpuruk adalah melemahnya daya beli masyarakat (termasuk warga jam'iyyah Nahdlatul Ulama) karena dominasi dolar terhadap rupiah. Jika kondisi ini terus berlanjut, tentu saja kemiskinan akan semakin merajalela dan angka pengangguran akan semakin meningkat.

Mengacu pada persoalan ini, yang menjadi pertanyaan adalah, di mana letak eksistensi dan kepedulian NU dengan doktrin aswaja yang dimilikinya? Apakah doktrin asawaja hanya berkutat dalam persoalan ubudiyyah ${ }^{2}$ semata atau justru bisa menyentuh ke dalam persoalan masyarakat yang sangat vital seperti ekonomi?

Dalam kajian antropologi budaya, melemahnya nilai tukar rupiah terhadap dolar yang berpotensi munculnya krisis ekonomi dan merusak sendi-sendi kehidupan masyarakat seperti 1998 merupakan salah satu bentuk the culture of symbolism. Kultur simbolisme adalah suatu keadaan yang merepresentasikan sebuah gejala sosial ekonomi-dalam hal ini realitas ketidakstabilan perekonomian bangsa Indonesia-yang diwujudkan dalam simbol yang merefleksikan makna sikap ewuh pakewuh ${ }^{3}$ organisasi keagmaan, atau pun para

2 Maksud persoalan ubudiyyah adalah persoalan yang hanya berkutat dalam ritual keagamaan seperti shalat, haji, zakat, serta kajian-kajian tentang fiqih. Dalam banyak kasus, seringkali NU hanya terjebak dalam persoalan ubudiyyah semacam itu ketika mengimplementasikan doktrin aswaja di tengah masyarakat. Akibatnya, sulit dihindari bahwa aswaja hanyalah sekadar kerangka paham keagamaan NU yang tidak mengusung isu-isu populis. Lihat, Muhammad Abdul Mannan, Paham Keagamaan NU dan Persoalan Krusial Kemasyarakatan, (Jakarta: Uzair Press, 2006), hlm. 122.

${ }^{3}$ Ewuh pakewuh sebenarnya adalah bahasa dan istilah orang Jawa yang bermakna "keengganan", kemalasan, sikap tebang pilih, pamrih, serta kelambatan dalam mengambil sebuah tindakan, sehingga tidak mendatangkan hasil yang maksimal. Lihat, Rasuni Murka'ie, Mitos dalam Kosmologi Jawa, (Yogyakarta: LKiS, 1997), hlm. 207. 
pengemuka agama(Geertz 1973; Gupta \& Ferguson 1992).

Dalam hal itu, simbol yang ditampilkan adalah melemahnya nilai tukar rupiah terhadap dolar yang setiap saat menjadi ancaman nyata terhadap stabilitas nasional. Minimnya gebrakan dan campur tangan organisasi keagamaan-dalam hal ini adalah NU—merupakan potret tidak adaya kontribusi dari doktrin aswaja sebagai paham keagamaan NU. Padahal, doktrin aswaja sejatinya adalah pengejawantahan dari cara keberagamaan orang-orang NU yang hendak menampilkan Islam sebagai rahmatan lil'alamin, yaitu Islam yang memberikan manfaat bagi segala dimensi kehidupan umat, termasuk dimensi ekonomi mikro dan makro.

Sejauh ini, tidak banyak organisasi keagamaan di Indonesia yang memiliki cetak biru secara komprehensif, solid, dan meyakinkan bagaimana mengatasi problematika ekonomi yang dapat mengarahkan masyarakat menjadi sejahtera dan makmur. Padahal, bila merujuk pada pandangan antropolog Akhil Gupta dalam The Anthropology of the State (2006), fenomena ketidakstabilan ekonomi yang terjadi di Indonesia seperti saat ini dapat dijadikan sebagai media yang disebut the imagination of the state power. ${ }^{4}$ Yaitu, bagi NU yang ingin membuktikan bahwa organisasi keagamaan terbesar di Indonesia itu adalah organisasi yang menyentuh segala persoalan kehidupan bangsa dan negara (tidak hanya persoalan agama), maka isu ketidakstabilan ekonomi dapat menjadi tema besar program kerja NU. Hal itu sesuai dengan salah satu qawaid fiqhiyyah yang menjadi salah satu pedomnan NU yang berbunyi:

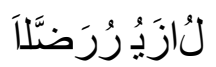

Artinya: "kemudharatan (bahaya) harus dihilangkan". 5

Qawaid fiqhiyyah yang menjadi pedoman NU di atas selayaknya diterapkan dalam konteks penyelesaian problematika kebangsaan, tidak hanya dalam wacana formulasi fiqih. Di sinilah pentingnya mereformulasi teks dan wacana keagamaan warga NU.

\footnotetext{
${ }^{4}$ Akhil Gupta, The Anthropology of the State, (Leiden: Brill, 2006), hlm. 285-294.
}

${ }^{5}$ Qawaid fiqhiyyah tersebut sangat terkenal di kalangan warga NU. Bahkan, qawaid fiqhiyyah tersebut selalu dijadikan landasan dan pijakan oleh NU ketika membahas persoalan fiqih dalam forum bahtsul masail NU. Sayangnya, penarapan qawaid fiqhiyyah tersebut hanya berkutat dalam tataran wacana fiqih, tidak masuk dalam persoalan sendi-sendi kehidupan ekonomi masyarakat secara konkret. 
Namun, bukan berarti isu ketidakstabilan ekonomi dan segala problematika kebangsaan lainnya hanya dijadikan sebagai strategi pencitraan NU semata (the imagination of the state power), tanpa melahirkan tindakan konkret untuk menyelamatkan kehidupan masyarakat luas. Stephen Van Evere (1997), mengatakan, tanggung jawab organisasi keagamaan di dunia yang mengangkat isu persoalan sosial, keagamaan, ekonomi, hukum, budaya, kesehatan, adalah mewujudkan kondisi yang jauh lebih baik dari keadaan sebelumnya. Stephen Van Evere mencontohkan kiprah OKI (Organisasi Kerjasama Islam) yang acap kali memberikan kontribusi penting bagi kehidupan umat muslim di dunia dalam persoalan ekonomi, pendidikan, dan kesehatan (bukan hanya persoalan kerukunan antara umat beragama). ${ }^{6}$

Untuk itu, dalam persoalan ekonomi, misalnya, NU merasa perlu menunjukkan kepada publik bahwa ia memiliki komitmen kuat untuk mengatasi masalah stabilitas ekonomi, kemiskinan, melemahnya nilai tukar rupiah terhadap dolar, melonjaknya angka pengangguran, dan lain sebaginya. ${ }^{7}$

Penting diketahui, secara orientatif, sikap keagamaan NU harus bertujuan untuk menegakkan kesejahteraan rakyat dalam segala aspek, tidak hanya menjadikan suatu obyek sebagai medium untuk membangun pencitraan dalam rangka memobilisasi simpati massa.

Lalu, bagaimana mensinergikan spirit perwujudan kesejahteraan masyarakat luas ${ }^{8}$ dengan sikap dan paham keagamaan NU dalam doktrin aswaja

6 Organisasi Kerja Sama Islam (dahulu Organisasi Konferensi Islam) (OKI) adalah sebuah organisasi internasional dengan anggota 57 yang memiliki seorang perwakilan tetap di Persirakatan bangsa-Bangsa. OKI yang didirikan di Rabat, Maroko pada 12 Rajab 1389 H (25 September 1969) dalam Pertemuan Pertama para Pemimpin Dunia Islam yang diselenggarakan sebagai reaksi terhadap terjadinya peristiwa pembakaran Masjid al-Aqsha pada 21 Agustus 1969 oleh pengikut fanatik Kristen dan Yahudi di Yerussalem. Namun dalam perkembangannya OKI tidak hanya mengkat isu kerukunan umat beragama, tetapi juga mengangkat isu ekonomi, politik, pendidikan, dan kesehatan bagi umat muslim di seluruh dunia.

${ }^{7}$ Lebih jauh lagi, Stephen Van Evere mengatakan, apabila kelak organisasi keagamaan berhasil menunjukkan bahwa ia memiliki komitmen tinggi terhadap persoalan ekonomi (problematika kebangsaan) dan berhasil memberikan solusi konkret, maka ia telah berhasil membuktikan bahwa agama tidak melulu berkutat dalam urusan vertikal (ketuhanan), tetapi juga dalam urusan horizontal. Artinya, dalam konteks demikian, teks dan wacana keagamaan yang dikembangkan tidak hanya dimanifestasikan dalam kajiankajian normatif keagamaan, tetapi juga dalam persoalan-persoalan yang terjadi di tengah masyarakat. Lihat, Stephen Van Evere, Guide to Methods for Student of Political Science, (Ithaca dan London: Cornell University Press, 1997), 129.

8 Agar tidak salah memahami prioritas pembangunan oleh NU, yang harus diketahui adalah, pelestarian ekonomi serta perwujudan kesejahteraan rakyat dalam segala aspeknya tidak kalah pentingnya dengan ibadah-ibadah mahdhah seperti shalat, puasa, zakat, naik haji, dan lain sebagainya. Pasalnya, ada kesalahan pandangan di kalangan awam bahwa pelestarian ekonomi serta perwujudan kesejahteraan rakyat dalam segala aspeknya tidak begitu penting biladibandingkan dengan ibadah mahdhah. 
sebagai cita-cita negara kesejahteraan yang berwatak populis? Pertanyaan inilah yang akan dibahas lebih lanjut dalam tulisan ini sekaligus sebagai upaya mengkontekstualisasi aswaja dalam rangka untuk mereformulasi teks dan wacana keagamaan warga NU sdengan tujuan untuk menegakkan kesejahteraaan kehidupan bangsa dan negara.

\section{KONTEKSTUALISASI ASWAJA: UPAYA PENINGKATAN EKONOMI}

Berangkat dari sekelumit analisa di atas, perlu sekiranya dilakukan aktualisasi dan kontekstualisasi doktrin aswaja yang menjadi paham keagamaan NU agar peduli terhadap berbagai macam problematika kebangsaan. Sehingga, ciri khas dan karakter NU tidak hanya identik dengan pondok pesantren yang mendidik kaum bersarung, pengajian kitab kuning, tetapi juga identik dengan kiprahnya di bidang ekonomi, pendidikan, kesehatan, budaya, dan lain-lain. Dalam konteks ini, diantara sedikit organisasi keagamaan yang peduli terhadap persoalan-persoalan bangsa, NU sebenarnya adalah salah satu ormas yang memiliki komitmen untuk mewujudkan Indonesia sejahtera dalam segala dimensi strategis. Hal itu ditandai dengan adanya beberapa bidang usaha NU.

Pertama, di bidang agama, NU berusaha melaksanakan dakwah Islamiyah dan meningkatkan rasa persaudaraan yang berpijak pada semangat persatuan dalam perbedaan. Kedua, di bidang Ekonomi, NU berupaya menyelenggarakan lembaga ekonomi yang sesuai dengan nilai-nilai Islam, untuk membentuk muslim yang kuat secara ekonomi, memberantas kemiskinan, berpenghasilan yang cukup. Hal ini terbukti dengan lahirnya lembaga-lembaga ekonomi NU dan sudah tersebar di berbagai daerah khususnya di pulau Jawa. Ketiga, dii bidang sosial budaya, NU berupaya mewujudkan kesejahteraan rakyat serta kebudayaan yang sesuai dengan nilai keislaman dan kemanusiaan. Keempat, di bidang ekonomi, NU mengusahakan pemerataan kesempatan untuk menikmati hasil pembangunan, dengan mengutamakan berkembangnya ekonomi rakyat. Hal ini ditandai dengan lahirnya BMT dan Badan Keuangan lain yang yang telah terbukti membantu

Oleh karena itu, reformulasi teks dan wacana keagamaan warga NU sangat penting dilakukan untuk menyadarkan masyarakat bahwa langkah peningkatan ekonomi, pendidikan, budaya, dan lain sebagainya, juga bernilai ibadah dan sebuah langkah yang sangat mulya di mata Tuhan. Lihat, Amirul Hasan, Pradigma Penerapan Islam Rahmatan Lil'alamin, (Yogyakarta: Media Presindo, 2006), hlm. 239. 
masyarakat. ${ }^{9}$

Tetapi, dalam perjalanannya, bidang-bidang usaha tersebut tidak berjalan seirama. Dalam bidang ekonomi dan pendidikan, misalnya, NU masih memberikan kontribusi yang minim terhadap bangsa dan negara. Selama ini NU lebih fokus pada usaha di bidang agama sehingga di berbagai daerah di Indonesia banyak muncul dakwah islamiyyah yang diprakarsai oleh NU.

Atas dasar itu, menurut hemat penulis, dalam rangka mewujudkan NU sebagai organisasi keagamaan yang memiliki perhatian penuh terhadap segala macam persoalan bangsa, perlu dilakukan kontekstulisasi aswaja sebagai upaya mereformulasi teks dan wacana keagamaan warga NU. Tujuannya adalah, agar NU semakin kuat menjadikan setiap isu dan problematika kebangsaan sebagai bagian integral dari komitmen NU.

Pada hakekatnya, NU berupaya menjangkau seluruh lapisan masyarakat tanpa mengenal batasan agama, budaya, golongan, serta berupaya menyentuh segala aspek, baik dalam pendidikan, agama, ekonomi, termasuk juga lingkungan hidup. ${ }^{10}$ Oleh karena itu, untuk menyikapi berbagai macam persoalan kebangsaan yang terjadi seperti saat ini, sebagai langkah kontekstualisasi doktrin aswaja, NU sangat perlu menanamkan lima konsep dasar.

Pertama, reference. Yaitu, penanaman kesadaran dan keyakinan bagi seluruh jama'ah nahdliyyin di nusantara mengenai pentingnya beribadah melalui dimensi horizontal, yaitu upaya untuk menghilangkan angka kemiskinan dan peningkatan ekonomi. Langkah ini dapat ditempuh dengan cara mengampanyekan pentingnya menjaga kestabilan ekonomi, kewirausahaan, baik dalam jangka menengah maupun dalam jangka panjang. Sebagai contoh, dalam jangka menengah, NU harus menghidupkan lembaga-lembaga ekonomi yang memberikan edukasi kepada masyarakat secara konkret. Sedangkan dalam jangka panjang NU harus mampu melahirkan kader-kader potensial yang memiliki ahli dan kompetensi di bidang ekonomi, bukan hanya di bidang keagamaan. Hal itu sebagai upaya untuk menghilangkan angka kemiskinan dan peningkatan ekonomi

9 Ahmad Nurhasim dan Nur Khalik Ridwan, Demoralisasi Khittah NU dan Pembaruan, (Yogyakarta: Pustaka Tokoh Bangsa, 2004), hlm. 55.

${ }^{10}$ Ibid. 
secara nasional.

Secara de facto, perlu dilakukan penyadaran bagi seluruh warga nahdliyyin bahwa langkah semacam ini sangat ditekankan dalam agama dan menjadi kewajiban bagi setiap umat Islam.

Perlu disadari bahwa aswaja sebagai paham keagamaan yang dianut oleh NU adalah sebuah pola pikir yang mengambil jalan tengah antara ekstrim 'aqli (rasionalis) dengan kaum ekstrim naqli (skripturalis). Hal ini telah ditegaskan dalam beberapa pijakan, yaitu:

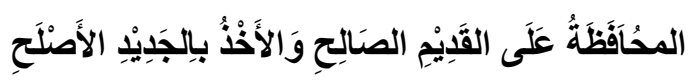

Artinya: Melestarikan (nilai-nilai) lama yang relevan dan mengadopsi (metode) baru yang lebih relevan

Hadis Nabi:

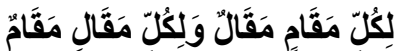

Artinya: "Sebaik-baik perkara itu adalah pertengahannya"

Dengan kata lain, pemikiran NU tidak hanya merujuk pada al-Qur'an, Sunnah, tetapi juga menggunakan kemampuan akal dan ditambah dengan realitas empirik. Realitas empirik tersebut bisa diterjemahkan sebagai segala macam problematika yang terjadi di tengah masyarakat seperti persoalan ekonomi, politik, pendidikan, kesehatan, dan lain-lain. Sehingga, gerakan NU tidak hanya bertumpu pada persoalan ibadah dan fiqih, tetapi juga bertumpu pada persoalan nyata yang terjadi di tengah masyarakat.

Bahkan, tokoh-tokoh yang menjadi sumber pemikiran NU sebenarnya telah mengajarkan pentingnya mengintegrasikan antara agama dan ekonomi, pendidikan, kesehatan, dan lain-lain. Misalnya, sebagaimana yang diakui dalam aswaja (paham keagamaan NU), dalam bidang teologi, NU merujuk kepada Abu Hasan Al-Asy'ari dan Abu Mansur Al-Maturidi, seorang tokoh yang menghasilkan rumusan dan konsep teologi yang bersifat populis. Artinya, dimensi ekonomi, politik, pendidikan, kesehatan, juga diakomudir dalam teologi Abu Hasan Al-Asy'ari dan Abu Mansur Al-Maturidi sebagai bagian dari takdir, qodha', qodhar, otoritas Allah dalam menentukan bagian manusia tentang ekonomi dan umur, dan lain sebagainya. ${ }^{11}$

11 M Amin Syukur, dkk, Teologi Islam Terapan: Upaya Antisipatif Terhadap Hedonisme 
Dalam bidang fikih, NU merujuk kepada empat madzhab; Hanafi, Maliki, Syafi'i, dan Hanbali, yang keempatnya adalah tokoh yang sangat gigih memberikan perhatian terhadap persoalan kemasyarakatan dalam berbagai bidang. Hal itu bisa kita lihat dari rumusan fiqih mereka yang juga menyinggung persoalan ekonomi, pendidikan, bahkan kesehatan. ${ }^{12}$

Dalam bidang tasawwuf, NU mengembangkan metode Al-Ghazali dan Junaid Al-Baghdadi, yang mengintegrasikan antara tasawuf dengan syariat. Artinya, kedua tokoh sufi ini menselaraskan antara dunia dan akhirat. ${ }^{13}$ Oleh karena itu, kini saatnya NU mengembangkan tafsir-tafsir dan rumusan fiqih yang bersifat populis dan memberikan solusi bagi segala macam problematika kebangsaan.

Kedua, respect. Yaitu, penanaman nilai-nilai kepada masyarakat luas untuk memperhatikan segala macam persoalan kemanusiaan berikut solusi untuk mengatasinya. Dengan demikian, warga nahdliyyin akan sanggup menghadapi persoalan ekonomi, pendidikan, budaya, sebagaimana mereka sanggup menghadapi persoalan keagamaan (fiqih) sebagaimana yang diajarkan di pesantren-pesantren. Lagkah ini pada dasarnya sesuai dengan ciri dan karakter NU, yaitu ciri humanisme religius (insaniyah diniyah), amat peduli dengan nilai-nilai kemanusiaan yang agamis yang berwawasan kebangsaan. Menjaga dan melestarikan tradisi yang baik serta mengambil hal-hal yang baru yang lebih baik untuk ditradisikan menjadi corak perjuangan yang ditempuh dengan cara-cara yang santun dan akhlak karimah. ${ }^{14}$

Ketiga, restrain. Yaitu, NU harus mengajarkan kepada seluruh masyarakat Indonesia-khususnya seluruh warga nahdliyyin — untuk selalu mengelola dan mengontrol ekonomi agar penggunaannya tidak mubadzir. ${ }^{15}$ Selain itu, NU juga

Kehidupan Modern, (Solo: Tiga Serangkai, 2005), hlm. 187.

${ }^{12}$ Muhammad Bagir, Fiqih Praktis I Menurut Al-Qur'an, As-Sunnah, dan Pendapat ParaUlama, (Bandung: Penerbit Karisma, 2008), 65.

${ }^{13}$ M Abdul Mujieb, Ensiklopedia Tasawwuf Imam Ghazali, (Jakarta: Penerbit Hikmah,2009), hlm. 43.

${ }^{14}$ Islahuddin, Gus Dur Menertawakan NU, (Ciputat: Penerbit nawas, 2010), hlm. 77

15 Menurut Syaikh Imam Al Qurthubi, mubadzir adalah tindakan berlebih-lebihan, menghamburhamburkan sesuatu dan penggunaannya tidak menghasilkan sesuatu yang bermanfaat. Bahkan cenderung mendatangkan dampak negatif Misalnya, menebangi hutan secara liar, menggunakan air, listrik secara membabi buta, sehingga muncul krisis lingkungan. Lihat, tafsir Al Qurthubi, Ta'liq: Muhammad Ibrahim Al Hifnawi, Takhrij: Mahmud Hamid Utsman, terj. Al jami' Li ahkam Al Qur'an, (Jakarta: Pustaka Azzam, 2007), hlm. 143. 
harus merumuskan fiqih yang mampu mensinergikan antara ibadah, ekonomi, pendidikan, dan kesehatan, sehingga nantinya akan tercipta warga nahdliyyin yang kaffah, yaitu ahli di bidang ilmu agama dan ilmu eksakta. Dalam hal ini, NU harus mampu memanfaatkan kader-kadernya yang duduk di lembaga legislatif (DPR), eksekutif (kabinet), untuk memperjuangkan produk peraturan perundangundangan yang menghilangkan dikotomi antara pendidikan agama dan umum. Pasalnya, selama ini masih terjadi dikotomi antara ilmu agama dan umum. Akibatnya, santri pesantren hanya dianggap bisa mengaji kitab kuning tanpa menguasai ilmu eksakta, sementara para siswa sekolah umum dianggap menguasai ilmu eksakta dan awam di bidang agama.

Berkaitan dengan hal itu, bila NU gencar menyuarakan pentingnya integrasi antasi ilmu agama dan umum serta mampu melahirkan rumusan fiqih yang populis, maka tesis David Harvey, dalam tulisan tentang Islam: Sebuah Agama Horizontal dan Vertikal? (Asian Survey, Juli 2002) patut dibenarkan. Dikemukakan, kesenjangan antara norma agama dan dunia muncul karena kegagalan para pengemuka agama dalam menintegrasikan antara ilmu-ilmu agama dan ilmu-ilmu eksakta. Padahal, agama hadir untuk semesta alam raya yang manfaatnya bisa dirasakan oleh seluruh mahluk di dalam segala dimensi dan di setiap ruang dan waktu,.

Keempat, redistribution. Yaitu, NU harus mengajarkan kepada masyarakat tanpa pandang bulu untuk mengembangkan kesalehan sosial berupa kemampuan untuk menyebarkan kekayaan, kegembiraan dan kebersamaan melalui langkah kedermawanan kepada sesama makhluk Tuhan ${ }^{16}$ dan lingkungan hidup.

Dengan demikian, NU tidak lagi hanya berkutat pada masalah-masalah keagamaan dengan mengusung isu-isu primordial, tetapi juga harus beranjak ke aspek-aspek riil masyarakat di level akar rumput, baik di tingkat mikro maupun makro. Caranya adalah dengan menanamkan nilai-nilai moral sehingga manusia memiliki kemampuan tinggi untuk mengatasi masalah-masalahnya dengan tanpa merusak harmoni dengan sumber daya ekonominya dan lingkungannya.

Kelima, responsibility. Yaitu, NU mengajarkan bahwa hidup di dunia

${ }^{16}$ Yang dimaksud dengan langkah kedermawanan kepada sesama mahluk Tuhan adalah jangkauan NU yang tidak membedakan agama, apa pun agamanya. Langkah ini sesuai dengan doktrin aswaja yang menekankan at-tawasuth dan at-ta'adul yang tidak mebedakan agama, suku, maupun goongan. 
adalah tanggung jawab kepada pencipta dan tanggung jawab dalam merawat stabilitas bangsa dan negara. NU dengan doktrin aswaja harus sadar bahwa pemanfaatan alam yang berlebihan selama ini telah menimbulkan dampak negatif yang besar bagi manusia dan alam itu sendiri. Misalnya, rusaknya hutan, bencana banjir, tercemarnya air, tanah dan udara, merupakan contoh nyata dari hasil pemanfaatan sumberdaya alam yang berlebih-lebihan sehingga hal tersebut merusak ekonomi, kesehatan, dan menjadi pendidikan buruk bagi kader-kader nahdliyyin.

Berkaitan dengan tanggung jawab NU terhadap stabilitas kehidupan berbangsa dan bernegara, bila mengikuti refleksi Robert Bellah (Habits of the Heart, 1985), profesi, jabatan, dan peran sosial-politik tidak cukup dipahami sebagai job (tugas) atau career (karier), tetapi a calling or vocation (panggilan). Dengan demikian, keberhasilan tidak selalu diukur dari capaian ekonomis dan psikologis, tetapi juga capaian sosialnya, yakni kemaslahatan bersama, misalnya kesejahteraan dalam bidang ekonomi, pendidikan dan kesehatan. Artinya,dakwahdakwah para kiyai NU dari mimbar ke mimbar akan dianggap berhasil jika memberikan kontribusi berarti bagi capaian sosial dan kemaslahatan di bidang ekonomi, pendidikan dan kesehatan — tidak hanya di bidang keagamaan semata.

Hal ini sesuai dengan kaidah fiqih yang menjadi pegangan NU yang berbunyi:

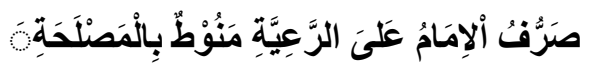

Artinya: "Suatu tindakan pemerintah berintikan terjaminnya kepentingan dan kemaslahatan rakyatnya”.

Atas dasar itu, sebagai upaya kontekstualisasi aswaja, NU harus terlibat aktif dalam perwujudan stabilitas bangsa, menjaga keutuhan NKRI, dan perjuangan menegakkan kesejahteraan rakyat dalam segala bidang.

\section{NU DAN POLITIK TATA RUANG}

Bila mencermati doktrin aswaja yang menjadi paham keagamaan NU, citacita NU sebenarnya bisa ditafsirkan untuk mewujudkan masyarakat yang terjamin hak asasi kemanusiaannya yang mengejawantahkan nilai-nilai kejujuran, kebenaran, kesungguhan dan keterbukaan bersumber pada hati nurani (as-shidqu), dapat dipercaya, setia dan tepat janji serta mampu memecahkan masalah-masalah 
sosial yang dihadapi (al-amanah wa al-wafa-u bi al-ahdli). Hal itu juga tercermin dari sosok imam al-Ghazali sebagai sumber pemikiran NU dalam bidang tasawwuf yang gigih memperjuangkan kemaslahatan dan keadilan dalam tulisantulisannya.

Dalam doktrin aswaja dikenal istilah al-amanah wa al-wafa-u bi al-ahdli. Bagi NU, konsep al-amanah wa al-wafa-u bi al-ahdli salah satunya harus diimplementasikan dengan mengaktualisasikan diri sebagai organisasi keagamaan yang pro bagi stabilitas ekonomi, politik (bukan terlibat politik praktis), pendidikan, kesehatan, dan budaya. Berkaitan dengan itu, bila diperhatikan, berbagai macam persoalan bangsa seperti melemahnya nilai tukar rupiah, meningkatnya angka pengangguran, kemiskinan, pelayanan pendidikan dan kesehatan yang tidak merata, maraknya kasus korupsi dan dan jual beli perkara, adalah indikasi konkret adanya kesalahan dalam menjalankan sistem politik tata ruang dalam menjaga dan melindungi masyarakat luas. Fungsi pemerintah tidak berjalan sebagaimana mestinya, bahkan berawal dari kesalahan dalam menjalankan sistem politik tata ruang, pada akhirnya masyarakat yang harus menanggung risiko negatifnya.

Undang-Undang Nomor 26 Tahun 2007 Tentang Penataan Ruang tidak mampu diterjemahkan oleh jajaran pemerintah pusat dan daerah. ${ }^{17}$ Eksistensi pemerintah untuk melindungi masyarakat Indonesia dari dampak ancaman krisis ekonomi, mahalnya biaya pendidikan dan kesehatan, kali terhalang oleh jeratan koordinasi dan egoisme sektoral serta kepentingan otonomi daerah. Di sisi yang lain, wewenang untuk menindak, menghentikan, melarang, dan mengingatkan tidak sepenuhnya dijalankan. Sebagai contoh, kegagalan dalam mengurangi angka pengangguran, pemberian lapangan kerja yang memadai, kelalaian dalam alih fungsi hutan, alih fungsi lahan pertanian, serta longgarnya perizinan di kawasan lindung dan resapan air, pada umumnya terjadi merata di setiap wilayah kota dan kabupaten.

Degan kata lain, proses politik antara pemerintah pusat dengan pemerintah daerah tidak berjalan sebagimana mestinya. Naifnya lagi, dalam proses perencanaan tata ruang, partisipasi organisasi kemasyarakatan seperti NU sangat

17 Undang-Undang ini sebenarnya sebenarnya ditekankan adanya koordinasi antara pemerintah pusat dengan pemerintah daerah bail di level propindi maupun kabupaten, bahkan melibatkan partisipasi masyarakat. Lihat, UU Nomor 26 Tahun 2007 Tentang Penataan Ruang. 
minim. Pantas bila Conyers (1981), berpendapat bahwa pada dasarnya perencanaan tidak lain merupakan sebuah proses politik yang menimbulkan adanya persaingan antar kelompok.

Di sinilah sebenarnya NU dituntut untuk mengedepankan unsur partisipasi publik dalam proses politik (bukan politik yang berorientasi kekuasaan), khususnya yang berkaitan dengan perencanaan tata ruang. Konsepsi partisipasi masyarakat dapat dilihat dari berbagai perspektif, antara lain perspektif sosial, politik, dan kewargaan. ${ }^{18}$

Adanya penekanan partisipasi NU dalam politik tata ruang pada dasarnya sesuai dengan spirit dan doktrin aswaja, yaitu unsur musyawarah dalam menyelesaikan persoalan sosial (al-syuro) yang menempatkan demokrasi sebagai pilar utamanya dan persamaan kedudukan setiap warga negara didepan hukum (almusawa) adalah prinsip dasar yang harus ditegakkan. Dalam konsep al-syuro sebagaimana yang ditekankan pandangan keagamaan NU (aswaja), partisipasi masyarakat menjadi hal yang sangat penting.

Oleh karena itu, sebagai upaya perwujudan partisipasi publik, untuk memanifestasikan konsep al-syuro di tubuh NU, menurut hemat penulis setidaknya ada tiga substansi yang perlu dicermati. Pertama, hak dan tindakan masyarakat menyampaikan aspirasi, gagasan kebutuhan, kepentingan, dan tuntutan terhadap komunitas terdekatnya maupun kebijakan pemerintah. Kedua, ruang dan kapasitas masyarakat dalam mempengaruhi dan menentukan kebijakan serta terlibat aktif mengelola barang-barang publik. Ketiga, kontrol masyarakat terhadap lingkungan dan komunitasnya maupun proses politik yang terkait dengan pemerintah.

Apabila NU berhasil mewujudkan ketiga substansi tersebut dalam upaya menanggulangi berbagai macam persoalan kebangsaan, maka masyarakat akan lebih respon terhadap produk perencanaan tata ruang. Misalnya, program penghijauan, pelestarian hutan, pemanfaat sarana air secara komprehensif, dan lain sebagainya. Dalam orientasi jangka panjang, langkah NU ini akan melahirkan

${ }^{18}$ Salah satu pengertian partisipasi publik adalah bahwa partisipasi publik merupakan keikutsertaan dalam proses formulasi, pengesahan, dan pelaksanaan kebijakan pemerintah yang dilakukan secara legal oleh warga perorangan atau swadaya yang secara langsung atau tidak langsung ditujukan untuk mempengaruhi pilihan pejabat pemerintah dan/atau tindakan mereka. Di sinilah NU seharusnya mengambil peran aktif. Lihat, Wanjat Kastolani, Pendidikan Kependudukan Dan Lingkungan Hidup, (Jakarta: Quadra Mitra Melati, 1995), hlm. 76. 
rasa memiliki dan tanggung jawab dalam merencanakan dan melaksanakan program-program pemerintah dalam segala bidang. Bahkan, tidak hanya itu, kegiatan pelaksanaan menjadi lebih obyektif dan fleksibel berdasarkan keadaan setempat, dan pelaksanaan program lebih terfokus pada kebutuhan masyarakat. Dengan cara semacam ini, Undang-Undang Nomor 26 Tahun 2007 Tentang Penataan Ruang akan terlaksana secara maksimal, serta tertanam di hati masyarakat akan tanggung jawab terhadap segala macam persoalan bangsa. Semoga!

\section{KESIMPULAN}

Dari uraian panjang lebar dalam tulisan ini, kesimpulan yang bisa diambil adalah bahwa kontekstualisasi doktrin aswaja sebagai upaya mereformulasi teks dan wacana keagamaan warga NU adalah sebuah keniscayaan yang tak terelakkan. Dengan langkah itu, NU akan semakin terlibat aktif dan konkret dalam persoalanpersoalan kebangsaan.

Namun, jalan menuju kondisi itu memerlukan proses panjang. NU tidak boleh bosan untuk terus membudayakan pemahaman yang mengintegrasikan antara teks-teks agama dengan persoalan-persoalan horizontal. Hal tersebut harus ditanamkan di level akar rumput (masyarakat nahdliyyin) sebagai basis NU, bukan dalam seminar dan diskusi elite yang tidak membumi. Harus diakui, betapa langkanya kini organisasi keagamaan yang menitikberatkan perhatian pada persoalan-persoalan ekonomi, pendidikan, kesehatan, budaya, dan segala hal yang menjadi masalah kekinian.

Meski selama ini NU lebih banyak bergerak di ranah keagamaan, namun hendaknya NU tetap memberikan ruang integrasi berbagai kearifan (keilmuan, budaya, politik, ekonomi, dsb), untuk menjadi kanal dari terbentuknya transformasi sosial, serta menyediakan wahana untuk menyadarkan masyarakat (warga nahdliyyin) tentang pentingnya perhatian terhadap persoalan-persoalan kebangsaan.

\section{DAFTAR PUSTAKA}

Al Qurthubi, Ta'liq: Muhammad Ibrahim Al Hifnawi, Takhrij: Mahmud Hamid Utsman, terj. Al jami' Li ahkam Al Qur'an, Jakarta: Pustaka Azzam, 2007.

Bagir, Muhammad, Fiqih Praktis I Menurut Al-Qur'an, As-Sunnah, dan Pendapat 
Para Ulama, Bandung: Penerbit Karisma, 2008.

Eric Katz, Judaism and the Ecological Crisis dalam Mary Evelyn Tucker \& John A. Grimm (Ed), Worldviews and Ecology: Religion, Philosophy, and the Environment, New York: Orbis Books, 1994.

Evere, Stephen Van, Guide to Methods for Student of Political Science, Ithaca dan London: Cornell University Press, 1997. 
Gupta, Akhil, The Anthropology of the State, Leiden: Brill, 2006.

Islahuddin, Gus Dur Menertawakan NU, Ciputat: Penerbit nawas, 2010.

Hasan, Amirul, Pradigma Penerapan Islam Rahmatan Lil'alamin, Yogyakarta: Media Presindo, 2006.

Kastolani, Wanjat, Pendidikan Kependudukan Dan Lingkungan Hidup, Jakarta: Quadra Mitra Melati, 1995.

Mannan, Muhammad Abdul, Paham Keagamaan NU dan Persoalan Krusial Kemasyarakatan, Jakarta: Uzair Press, 2006.

Murka'ie, Rasuni, Mitos dalam Kosmologi Jawa, Yogyakarta: LKiS, 1997.

Mujieb, M Abdul, Ensiklopedia Tasawwuf Imam Ghazali, Jakarta: Penerbit Hikmah, 2009.

Nurhasim, Ahmad dan Nur Khalik Ridwan, Demoralisasi Khittah NU dan Pembaruan, Yogyakarta: Pustaka Tokoh Bangsa, 2004.

Syukur, M Amin, dkk, Teologi Islam Terapan: Upaya Antisipatif Terhadap Hedonisme Kehidupan Modern, Solo: Tiga Serangkai, 2005.

UU Nomor 26 Tahun 2007 Tentang Penataan Ruang. 